\title{
Intraguild predation among aphidophagous predators
}

\author{
ÉRIC LUCAS \\ Groupe de Recherche en Écologie Comportementale et Animale (GRECA), Département des Sciences Biologiques, \\ Université du Québec à Montréal, C.P. 8888 Succ. Centre-ville, Montréal, Qc, Canada H3C 3P8; e-mail: lucas.eric@uqam.ca
}

Key words. Intraguild predation, IGP, biological control, predation, aphidophaga, Coccinellidae, interaction

\begin{abstract}
Since the publication of papers by Polis et al. (1989, 1992), intraguild predation (IGP) has been considered in numerous systems and a growing number of papers have been published, demonstrating the ubiquity and the importance of this interaction. It appears that aphidophagous guilds constitute especially favourable systems for IGP. Temporal and spatial distributions of aphids promote interactions, such as IGP, among natural enemies. However, despite extensive laboratory and field studies, several questions remain to be answered: Which traits of the different protagonists of the system may promote or hamper the occurrence of IGP? How do ants tending aphids modulate the interaction? How should one consider the "sub-lethal" effects (and the defensive mechanisms) associated with the risk of IGP? May IGP disrupt or enhance aphid control? These different issues are discussed by focusing on the predatory species in the complex system of aphidophagous guilds. It appears that, first, IGP may constitute one of the main forces influencing the structure and dynamics of aphidophagous guilds, and therefore it has to be taken into account in research studies, and second, because of the ephemeral nature of aphid colonies and the great number of species belonging to aphidophagous guilds, understanding all the implications of the interaction, both direct and indirect, constitutes a very complex task.
\end{abstract}

\section{INTRODUCTION}

Gary Polis and colleagues $(1989,1992)$ modified the previous definition of a guild (Root, 1967) by including all species exploiting a similar resource, regardless of their nutrition mode, ecology, or taxonomic position. Then, they defined intraguild predation (IGP) as a predation event where a member of the guild preys upon another member of the same guild. The predator was defined as the intraguild predator, the prey (competitor) as the intraguild prey and their common resource as the extraguild prey (Fig. 1). IGP is usually characterized by evaluating its intensity, its direction, and its symmetry. The intensity refers to the level of IGP (for example, the proportion of replicates where IGP occurs) in a specified combination of predators (Lucas et al., 1998). The direction refers to the identity of the predator and the prey in the interaction. IGP can be unidirectional when one of the guild's members is always the prey and the other member always the predator, or mutual when the interaction goes in both directions, the predator becoming the prey and vice versa. In the case of mutual IGP, the symmetry can be evaluated by calculating an index of symmetry (the number of replicates in which a given predator was preyed upon divided by the total number of replicates in which there was IGP) and comparing it to a theoretical index of $50 \%$ corresponding to a symmetric interaction (Lucas et al., 1998). If a significant difference is detected, the interaction is considered as asymmetrical in favour of the organism more often preying on the other one; in the other case, the interaction is considered as symmetrical. Since the publications of Polis et al. (1989, 1992), a growing literature has demonstrated the ubiquity of the interaction in most animal communities.

Considering the outcome of the interaction, three scenarios can be envisaged; (1) the prey is killed and eaten
(IGP sensu stricto); (2) the prey is killed but not consumed (interspecific killing) and (3) the prey is not killed but IGP generates sublethal effects on the intraguild prey. I would enlarge the original definition by including the case of interspecific killing, since costs and benefits are similar except for the protein-rich meal for the predator. Several studies showed that the intensity of the interaction can be very high in specific systems. For example, Szeinfeld (1991) observed that in the Cape anchovy, Engraulis capensis, 56\% of the eggs were consumed by an intraguild predator, the sardine Sardinops ocellatus, and that $88 \%$ of the sardines captured had anchovy eggs in their stomach. In another example, IGP by the lion Panthera leo, constituted $72.2 \%$ of juvenile mortality in the cheetah Acinonyx jubatus, before young leave the lair (Laurensen, 1994).

It is now well established that IGP affects the intraguild predator, the intraguild prey and the extraguild prey, at the individual, the population and the community levels. It influences the ecological and evolutionary traits of the different protagonists (Polis et al., 1989; Polis \& Holt, 1992; Holt \& Polis, 1997).

In aphidophagous guilds, intraguild predation in Coccinellid assemblages has been reviewed by Dixon (2000) and by Omkar \& Pervez (2002). Brodeur \& Rosenheim (2000) also reviewed the literature on parasitoid interactions, and Rosenheim et al. (1995) reviewed IGP among biological control agents. Müller \& Brodeur (2002) discussed the implications of IGP in biological control programs and conservation management. My objective here is to review and update the literature on IGP that focuses on predatory aphidophagous species. Aphidophagous guilds, rich in species, provide very interesting systems for studying these interactions. Several questions will be addressed according to the available literature. 


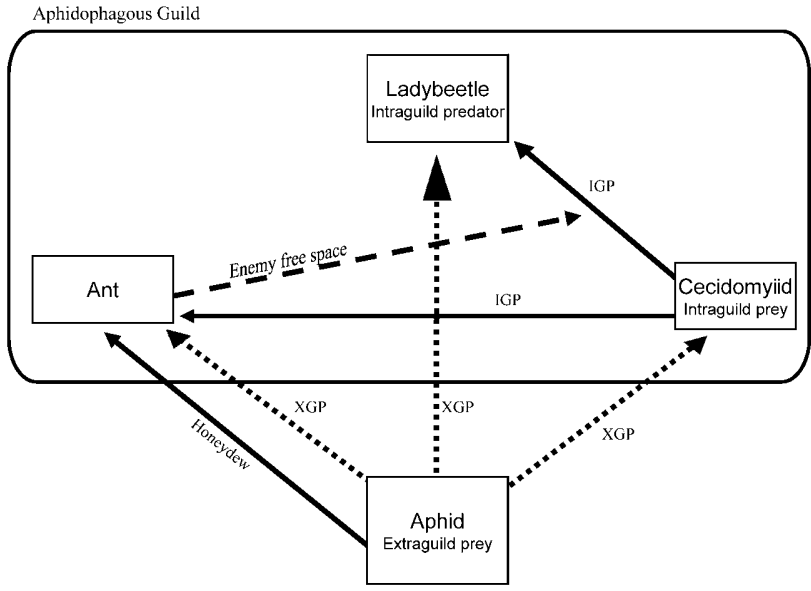

Fig. 1. An example of an aphidophagous system that includes ants that tend aphids. Arrows indicate the direction of the interaction, pointing toward the consumer/predator. IGP - Intraguild predation; XGP - Extraguild predation.

\section{WHAT IS THE IMPORTANCE OF IGP IN APHIDOPHAGOUS SYSTEMS?}

The first problem concerning IGP is associated with the fact that IGP, like cannibalism, is usually an ephemeral event, difficult to observe and quantify in the field. This may explain why intraguild predation has generated so little commentary in the literature before the publications of Polis et al. (1989, 1992). In aphidophagous systems, what is really the importance of IGP for predatory species? Is IGP really an important interaction or simply a laboratory artefact? I personally observed in the field IGP by an adult of the twelve spotted lady beetle Coleomegilla maculata on a larva of the midge Aphidoletes aphidimyza close to a colony of Aphis nerii on a milkweed plant. Since this time, numerous evidences from personal observations in different systems (e.g., Riudavets, Labrie, Laplante, pers. comm.) from video cameras experiments (Meyhöfer, 2001), and from the literature attest to the ubiquity of the interaction among aphidophagous predators (Table 1).

May aphidophagous systems promote IGP interaction? Aphidophagous guilds should constitute ideal systems for intraguild interactions for four main reasons. First, aphidophagous guilds are extremely diversified and include a great number of predatory, parasitoid and pathogenic species (Minks \& Harrewijn, 1988). Second, the individuals of most aphidophagous species experience a drastic change in their body-size during their life-cycle (an increase of at least ten times their initial size). This change creates many potential IGP situations by exposing small, highly vulnerable individuals to larger individuals of top-predators. Third, aphids, as the common food source, are contagiously distributed in space (Shaposhnikov, 1987). Accordingly, most aphidophagous species also distribute themselves contagiously (for example, through their numerical aggregative responses), thereby increasing encounter probability and then IGP probability. Fourth, aphids demonstrate also a contagious temporal distribution characterized by huge densities during brief periods. Most aphid colonies experience outbreaks followed by dramatic crashes during summer (see Dixon, 1985, 1987). Aphidophagous species should then concentrate on this narrow temporal window of prey availability. Other guilds, exploiting a resource with a similar concentration in time and space, such as necrophagous or coprophagous guilds for example, include numerous species that prey on other species both outside and within the guild (Hanski, 1987; Rozas et al., 1991; Agoiz-Bustamante, 2001). In the field, most aphid colonies are exploited simultaneously by several aphidophagous species.

Now, what is the importance of IGP in aphidophagous guilds? Most data collected to answer this question come from laboratory studies, and the extrapolation to IGP intensity in the field remains tenuous. Therefore, the best evidence of the importance of IGP is given by direct observations of focal individuals in the field. Rosenheim et al. (1999) followed neonate lacewing larvae in cotton fields, during $4 \mathrm{~h}$ periods of observation. Of 136 individuals, 9 were killed by intraguild predators; thus $6.6 \%$ died from IGP in a time period covering only about $1.4 \%$ of their total life cycle. These results provide evidence that IGP is a major source of mortality for lacewing neonate larvae in cotton fields; in this case, IGP was more frequent than cannibalism and death following dropping from the plant. Another example, in a psyllidophagous system, revealed that IGP on immature stages of the parasitoid, Tamarixia radiata (Waterson) by local predators resulted in $>95 \%$ mortality of the parasitoid in Florida citrus groves that were infested by the Asian psyllid Diaphorina citri Kuwayama (Michaud, 2004). In conclusion, IGP is very common in most aphidophagous systems and should constitute a primary mortality factor for the most vulnerable stages of some aphidophagous species. Very few studies are based on field observations, because such a research approach is time consuming and frequently complex. However, such studies are required to effectively assess the true intensity of IGP and to identify the intraguild prey and predators. The utilization of video systems in the field (Meyhöfer, 2001) may be a reliable technique to collect such data.

\section{WHO IS INVOLVED IN IGP?}

IGP in aphidophagous systems may implicate predators, parasitoids and pathogens. Predators, as intraguild prey, may be attacked by other predators, by generalist pathogens and also by some generalist parasitoids (see Rosenheim et al., 1995; Babendreier et al., 2003). As intraguild predators, they may prey upon infested or parasitized aphids (Brodeur \& Rosenheim, 2000; Brodeur \& Boivin, 2004) or upon other predatory species. As stated before, the predatory aphidophagous guild is particularly rich, including at least 12 families. Among them, coccinellids (Dixon, 2000; Omkar \& Pervez, 2002), carabids (Lang, 2003), chrysopids (Sengonca \& Frings, 1985; Lucas et al., 1997, 1998), syrphids (Hindayana et al., 2001), cecidomyiids (Lucas et al., 1998; Lucas \& Brodeur, 1999, 2001), nabids (Rosenheim et al., 1999), 
TABLE 1 . Some selected studies on intraguild predation among aphidophagous predatory species.

\begin{tabular}{|c|c|c|c|c|}
\hline Reference & Type & Subject & Predatory species & $\begin{array}{l}\text { Family/func- } \\
\text { tional group }\end{array}$ \\
\hline Agarwala \& Dixon, 1992 & $\mathrm{~L}$ & nutritional benefit/cost & $\begin{array}{c}\text { Coccinella undecimpunctata, Coccinella sep- } \\
\text { tempunctata, Adalia decempunctata, Adalia } \\
\text { bipunctata }\end{array}$ & Coccinellidae \\
\hline Agarwala \& Yasuda, 2001 & $\mathrm{~L}$ & egg defense & $\begin{array}{c}\text { Menochilus sexmaculatus, } \\
\text { Coccinella transversalis }\end{array}$ & Coccinellidae \\
\hline Burgio et al., 2002 & $\mathrm{~L}$ & cannibalism and IGP, aphid density & Harmonia axyridis, Adalia bipunctata & Coccinellidae \\
\hline Cottrell \& Yeargan, 1998 & $\mathrm{~L}$ & nutritional benefit/cost & Harmonia axyridis, Coleomegilla maculata & Coccinellidae \\
\hline De Clercq et al., 2003 & $\mathrm{~L}$ & nutritional cost, lepidopteran prey & $\begin{array}{c}\text { Harmonia axyridis } \\
\text { Podisus maculiventris }\end{array}$ & $\begin{array}{l}\text { Coccinellidae } \\
\text { Pentatomidae }\end{array}$ \\
\hline Félix \& Soares, 2004 & $\mathrm{~L}^{*}$ & body size effect & $\begin{array}{c}\text { Harmonia axyridis, } \\
\text { Coccinella undecimpunctata }\end{array}$ & Coccinellidae \\
\hline Hemptinne et al., 2000a & $\mathrm{L}$ & nutritional benefit/cost & Coccinella septempunctata, Adalia bipunctata & Coccinellidae \\
\hline Hemptinne et al., 2000b & $\mathrm{L}$ & nutritional cost, chemical signal & Coccinella septempunctata, Adalia bipunctata & Coccinellidae \\
\hline Hindayana et al., 2001 & $\mathrm{~L}$ & $\begin{array}{c}\text { relative body size, defense, } \\
\text { aphid density }\end{array}$ & $\begin{array}{c}\text { Episyrphus balteatus } \\
\text { Chrysoperla carnea } \\
\text { Coccinella septempunctata } \\
\text { Aphidoletes aphidimyza }\end{array}$ & $\begin{array}{l}\text { Syrphidae } \\
\text { Chrysopidae } \\
\text { Coccinellidae } \\
\text { Cecidomyiidae }\end{array}$ \\
\hline
\end{tabular}

Kajita et al., 2000

Lucas \& Alomar, 2001

Lucas \& Alomar, 2002a

Lucas \& Brodeur, 2001

Lucas et al., 1998

Mallampali et al., 2002

Michaud, 2002

Michaud \& Grant, 2003

L aphid density, sublethal effect

zoophytophagy, nutritional benefit/cost

FC zoophytophagy, plant damage

$\mathrm{L} \quad$ dillution effect, defense

L aphid density, body size, mobility

L biological control, coleopteran prey

L nutritional benefit/cost

L morphol. defense, mobility

Obrycki et al., 1998a

Obrycki et al., 1998b

FC larval survival, aphid density

Omkar et al., 2004

FC development, survival, aphid

L density

Phoofolo \& Obrycki, 1998

Rosenheim et al., 1999

F survival, mortality factor

Roy et al., 2003

L IGP on entomopathogen

Schellhorn \& Andow, 1999a F, L

Schellhorn \& Andow, 1999b F

Snyder et al., 2004a F

aphid density, dispersal

IGP on parasitoid, biological control

Yasuda \& Kimura, 2001

L

ladybeetle larval survival, aphid density, sublethal effects

Yasuda \& Ohnuma, 1999 L nutritional benefit/cost

Yasuda et al, 2001

$\mathrm{L}$
Coccinella septempunctata, Harmonia axyridis, Adalia bipunctata

Macrolophus caliginosus, Dicyphus tamaninii

Macrolophus caliginosus, Dicyphus tamaninii Aphidoletes aphidimyza Chrysoperla rufilabris Coleomegilla maculata Aphidoletes aphidimyza Chrysoperla rufilabris Coleomegilla maculata Podisus maculiventris

Harmonia axyridis, Cycloneda sanguinea Chrysoperla rufilabris,

Curinus coeruleus, Olla V-nigrum, Harmonia axyridis

Coccinella septempunctata, Coleomegilla maculata

Coccinella septempunctata, Coleomegilla maculata

Coccinella transversalis, Propylea dissecta Harmonia axyridis, Coleomegilla maculata, Coccinella septempunctata

Chrysoperla carnea

Chrysoperla rufilabris

Geocoris pallens, Geocoris punctipes Nabis sp.

Zelus renardii

Orius tristicolor

Coccinella septempunctata Pandora neoaphidis

Adalia bipunctata, Coleomegilla maculata Adalia bipunctata, Hippodamia convergens, Coleomegilla maculata

Harmonia axyridis

Aphelinus asychis Misumenops tricuspidatus

Coccinella septempunctata, Harmonia axyridis, Propylea japonica

Coccinella septempunctata, Harmonia axyridis Coccinellidae Coccinella septempunctata, Harmonia axyridis Coccinellidae

* F - field study; FC - field cage study; L - laboratory study. 
reduviids (Rosenheim et al., 1999), mirids (Lucas \& Alomar, 2001; 2002a, b), anthocorids (Cloutier \& Johnson, 1993; Rosenheim et al., 1999), lygaeids (Rosenheim et al., 1999), and spiders (Wise, 1993; Hodge, 1999; Yasuda \& Kimura, 2001) were involved in intraguild interactions. In most cases, several stages are not implicated in the interaction; this is the case for aerial adults, for example, or for some pupal stages occurring in protected sites. The role of the protagonists in the interaction (prey or predator) is usually determined by the specific stages of the different species.

\section{Intraguild predators}

Some species at specific stages of their development may play the role of top-predators. This is the case for crab-spiders (Yasuda \& Kimura, 2001) and for the lady beetle Harmonia axyridis Pallas (Snyder et al., 2004b). Other generalist predators of large size, such as the reduviid Zelus renardii (Kolenati) (Rosenheim et al., 1993; 1999), and the pentatomid Podisus maculiventris (Mallampalli et al., 2002; De Clercq et al., 2003) may act as top intraguild predators or higher order predators (see Rosenheim, 1998). Stages of species with individuals of large size may play the predatory role in the interaction. However, in arthropod systems, each individual of any predatory species experiences several periods of great susceptibility during its life cycle, including during periods as eggs, young larval instars, the non mobile pupal stage or times of moulting (Fig. 2). When interacting with parasitized aphids, or aphids infested by pathogens, predators usually constituted the intraguild predators (but see Babendreier et al., 2003).

\section{Intraguild prey}

Some species of the guild are restricted to the role of the prey. This is the case for the cecidomyiid $A$. aphidimyza (Lucas et al., 1998) or for the Chamaemyiid Leucopsis americana Malloch (Guénard in prep.), which are specialized predators of small body size and low mobility. In other species, sessile and non mobile stages are preyed by intraguild predators. Eggs, when not protected for example by insertion in plant tissues (as in Mirids), are usually very susceptible (Dixon 2000). Pupal stages in holometabolous predators are also immobile and usually attacked by intraguild predators (Lucas et al., 2000), with some exceptions such as lacewing pupae (Lucas et al., 1998), or cecidomyiid pupae occurring in the soil (Nijveldt, 1988).

\section{Extraguild prey}

Aphids constitute the extraguild prey, as do more generally species of the super family of the Aphidoidea (Aphididae, Eriosomatidae, Adelgidae, Phylloxeridae). However, while some predators, such as A. aphidimyza, are specialized on aphids, others like lacewings or lady beetles have polyphagous habits and include in their diet spider mites, thrips, whiteflies and/or eggs and larvae of coleopteran and lepidopteran species (Principi \& Canard, 1984; Hodek, 1996). Numerous species belonging to different guilds may be implicated therefore in intraguild interactions at different levels. Furthermore, some species

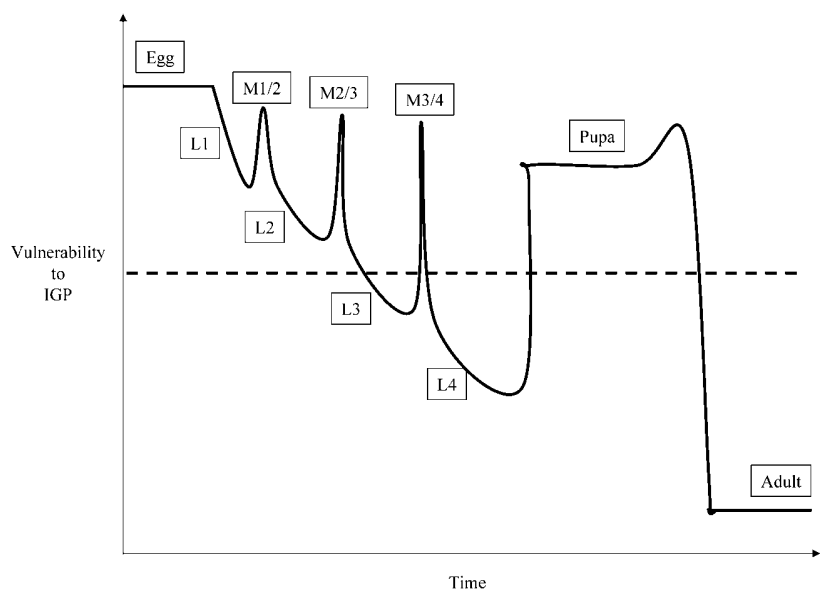

Fig. 2. Aphidophagous holometabolous insect's susceptibility to intraguild predation during its life cycle (in the case illustrated, including four instars). The horizontal line refers to a threshold of vulnerability linked to a potential intraguild predator. M1/2 - Moult from 1st to 2nd larval instar; L1 - 1st larval instar.

preying on aphids are also zoophytophagous, consuming both plant parts and aphids (Lucas \& Alomar, 2001; 2002a). For these species, a predation event on an aphid constitutes a formal case of intraguild predation (both species exploit the plant). Most of the discussion in the present paper may be applied not only to aphids, but more generally to gregarious insect prey with low mobility.

\section{WHEN AND WHERE IGP?}

Intraguild predation is strongly influenced by the characteristics of the system. IGP events occur mainly in specific conditions. In other situations, IGP should be rare but sublethal effects may be present. What characteristics of the system may promote or hamper IGP?

\section{Environmental characteristics}

Spatial scales of investigation may affect the occurrence and intensity of animal interactions (Englund, 1997). In the laboratory, the size of the arena may modify the intensity of the IGP, with small arenas generating higher levels of interaction than large ones (Chang, 1996; but see also Hindayana et al., 2001). In some studies, IGP that was previously quantified in the lab was not detectable in field or semi-field trials (Lucas \& Alomar, 2000; $2002 \mathrm{a} ; 2002 \mathrm{~b})$. Accordingly, feeding trials in laboratory may not constitute adequate systems to assess the intensity and direction of IGP in the field. Also, in the field or in the lab, the presence of a refuge for susceptible stages reduced IGP (Lucas et al., 2000). Human activity, including fertilizer use, IPM or biological control, or landscape management, may favour or hamper the interactions between predatory species. As an example, application of a sublethal dose of Lambda-cyhalothrin did not modify direct levels of intraguild predation but affected the mobility of the intraguild predators (Provost et al., 2003a) and resulted in increased mortality of the intraguild predator due to additional exposure to the product 
through intraguild prey consumption (Provost et al., 2003b).

\section{Plant characteristics}

Intraguild interactions might be affected by plant characteristics such as the presence of trichomes (Lucas \& Brodeur, 1999) and plant surface waxes (White \& Eigenbrode, 2000). Plants may provide refuges for the intraguild prey or may reduce predator mobility. For example, trichomes protect $A$. aphidimyza eggs against intraguild predation by the twelve-spotted lady beetle (Lucas \& Brodeur, 1999).

\section{Extraguild prey characteristics}

The presence of extraguild prey usually decreases the intensity of IGP (Lucas et al., 1998; Schellhorn \& Andow, 1999b; Hindayana et al., 2001; Burgio et al., 2002). The same tendency was observed for cannibalism among aphidophagous predators (Agarwala \& Dixon, 1992). For example, on unlimited aphid prey, the survival of $C$. maculata larvae was similar in the presence or absence of Coccinella septempunctata larvae, while at one aphid per day, it was significantly reduced in the presence of the heterospecific larvae (as a consequence of IGP, exploitative competition or both) (Obrycki et al., 1998b). Yasuda et al. (2004) showed that increasing food supply generated a faster rate of growth in intraguild prey and a decrease in IGP and exploitative competition among indigenous and introduced coccinellid species. Other types of responses to aphid density can be observed, such as a constant and strong intensity of IGP, or a decrease only at great aphid density (see Lucas et al., 1998). Levels of IGP between lady beetle larvae (3rd and 4th instar) did not decrease significantly when aphids were added in the microcosm (Snyder et al., 2004b), however only ten aphids were added for $8 \mathrm{~h}$ of experimentation. Colony age structure can also influence the intensity of IGP. For example, the presence of older aphids, which are more mobile, increased cecidomyiid susceptibility to lacewing predation (Lucas, unpubl.). Colony feeding site, geometry, density, and compaction could also have an impact on predator interactions.

\section{Intraguild prey characteristics}

Mobility / immobility

The low mobility or sedentary nature of a potential prey is associated with high vulnerability to IGP (Lucas, 1998; Lucas et al., 1998). Escape behaviour is one of the main defensive mechanisms used by insects. However, lack of such behaviour can sometimes be beneficial, since several predators, such as Episyrphus balteatus de Geer, have low predation rates on immobile prey (Hindayana et al., 2001).

\section{Predation strategy}

The midge $A$. aphidimyza is a furtive predator that spends its entire larval development within its prey colony and generates little defensive response by its aphid prey (Lucas \& Brodeur, 2001). This furtive behaviour reduces encounters with intraguild predators in comparison with the behaviour of active-searching lady beetle or lacewing larvae. In a completely different system, Johansson (1993) showed that damselfly larvae of Coenagrion hastulatum (Charp.), which capture prey by ambush, were less frequently attacked by the intraguild predator Aeshna juncea (L.) than were active-searching larvae of Leucorrhinia dubia (V. d. Lind.).

\section{Moulting / pupating phases}

During periods of moulting and pupating, most aphidophagous predators are highly vulnerable to intraguild predation. Coccinellids, for example, are immobilized during exuviation and devoid of hard tegument (Lucas et al., 2000). The pupal stage, despite more sclerified tegument, flipping behaviour, and defensive gin traps, was also a susceptible period in the lady beetle life cycle (Hironori \& Katsuhiro, 1997; Lucas et al., 1998, 2000; Félix \& Soares, 2004). Such an increase in vulnerability was not observed in pupal stages of other predators such as syrphids (Fréchette et al., in prep.), lacewings (Lucas et al., 1998), and cecidomyiids (pupation occurring in the soil).

\section{Intraguild predator characteristics}

\section{Feeding specificity}

In order to play the role of intraguild predator, the predatory species should be sufficiently polyphagous to include non-aphid prey in its diet. Almost all generalist species attacking aphids have been involved in IGP as intraguild predators (Table 1). At the opposite extreme, the specialist $A$. aphidimyza is restricted to the role of intraguild prey when confronted with $C$. maculata and $C$. rufilabris. However, this is not the case for the specialized E. balteatus which was observed both as an intraguild prey and predator (Hindayana et al., 2001).

\section{Relative size}

In most cases, the relative size of the opponents determines the outcome of the interaction, with larger individuals preying on smaller ones (Sengonca \& Frings, 1985; Lucas et al., 1998; Hindayana et al., 2001; Sato et al., 2003). A relatively larger body size is usually correlated with more vigor, more efficient weapons, and more efficient defensive mechanisms (see below). Félix \& Soares (2004) showed that, when mutual IGP occurred between $H$. axyridis and Coccinella undecimpunctata L. larvae, the relationship between the predation rate and the difference in body weight in intraguild predator and intraguild prey differed according to which species was the intraguild predator. For $H$. axyridis, a small difference in relative body weight generated a rapid increase in IGP intensity, but this was not the case for C. undecimpunctata L. (see also Yasuda et al., 2004). Snyder et al. (2004), testing different lady beetle combinations in microcosms, did not observe a significant relationship between the size advantage and the intensity of IGP.

\section{Historical and developmental factors}

Size, mobility, defensive abilities and duration of susceptible stages are influenced by historical and developmental factors. The history of colonization of the site in the fields, or the dates of releasing the predators, would determine what kind of potential confrontation may be 
observed at a specific time. Moreover, the time of development would determine the length of the window of vulnerability for the intraguild prey. According to the Slow Growth High Mortality hypothesis, a quicker development generates less mortality (Clancy \& Price, 1987). Thus, for example, depending on historical and developmental factors, larvae of a smaller predator species could be larger than larvae of a co-occurring larger predator species at a specific moment, and this may reverse the direction of the IGP. The differential response and persistence of aphidophagous predators to low aphid densities may also determine the structure and dynamics of the guild and consequently the occurrence and intensity of IGP (see Evans, 2004).

Since IGP experiments are rarely combined with population or community studies, it remains difficult to establish the consequences and frequency of such a behaviour. The importance of historical and developmental factors is crucial and should be taken into account when considering observations and experimental evidences of IGP in the lab and in the field. Time of colonization and timing of development appear to be especially crucial and rarely considered.

\section{WHY IGP?}

The occurrence of intraguild predation should be related to the adaptive value of preying upon a competitor. Advantages for the predator include (1) elimination of a potential predator (for example during moult), (2) elimination of a competitor, (3) obtainment of a protein-rich meal (Polis et al., 1989). Costs include (1) risk of being preyed upon by another predator, (2) risk of being injured, (3) risk of being contaminated by generalist pathogens and finally (4) risk of being poisoned by toxic compounds present in the intraguild prey (Polis et al., 1989; Dixon, 2000). According to these points, 4 scenarios of IGP can be proposed:

\section{Protective IGP}

In this case, the predator kills the intraguild prey in order to protect itself before a period of high vulnerability, and the consumption of the prey is facultative. Aquatic larvae of the culicid Toxorhynchites sp. enter a phase of "killing" at the end of their larval development before pupation and eliminate all invertebrate predators they encounter in their habitat (Corbet \& Griffiths, 1963). Such a scenario has not yet been documented in aphidophagous systems.

\section{Competitive IGP}

The predator selects the intraguild prey in order to eliminate a competitor, and the consumption of the prey is also facultative. In the necrophagous guild, one larva of the flesh fly Sarcophaga aratrix Pandelle can kill in three hours more than 40 larvae of the competitor Calliphora sp. (blow fly) (Blackith \& Blackith, 1984). As with protective IGP, this scenario remains hypothetical in aphidophagous guilds.

\section{Nutritional IGP}

The main benefit for the intraguild predator is the nutritional gain associated with IGP. Such IGP should be observed in systems where the nutritive value of the intraguild prey exceeds the value of the alternative food sources. Lucas \& Alomar (2001, in prep.) showed that the intensity of IGP between zoophytophagous mirids increased as the quality of the alternative food source decreased. This response may also be influenced by the presence of toxic compounds in the intraguild prey. Yasuda \& Ohnuma (1999) showed that consumption of legless larvae of the intraguild competitor $H$. axyridis resulted in high mortality of $C$. septempunctata larvae, but this was not the case when $H$. axyridis larvae were fed by $C$. septempunctata larvae. This illustrates that the response could be rather different for relatively similar predators.

\section{Opportunistic IGP}

In this case, the predator selects the prey according to its size regardless of the guild to which it belongs. Many aphidophagous predators have polyphagous habits and their prey choice is the result of a size selection rather than a species selection. The lacewing $C$. rufilabris seems to select indifferently intra or extraguild prey, and the occurrence of IGP is mainly determined by the encounter rate (Lucas et al., 1998).

Of course, each classification of natural or ecological events is obviously inadequate, at least in part because hybrid combinations may exist. Protective and competitive IGP may also be present in aphidophagous systems, and should be considered in analysing experimental results.

\section{IGP RISK AND SUBLETHAL EFFECTS}

IGP in some systems is absent or at very low levels of intensity, despite the simultaneous presence of aphidophagous predators and/or parasitoids (Lucas \& Alomar, $2002 a, b)$. This absence of interaction reflects the absence of lethal effects (predation or interspecific killing). However, very often, even in the absence of IGP, the risk of interaction generates indirect sublethal effects. Such sublethal effects have been identified in the literature on extraguild predation (Lima \& Dill, 1990; Lima, 1998). Unfortunately, these sublethal effects are rarely considered in studies on IGP.

In an aphidophagous-aleurophagous mirid system, Lucas \& Alomar (2002a, b) recorded a slower developmental time in the intraguild prey Macrolophus caliginosus (Wagner) in the presence of the intraguild predator Dicyphus tamaninii Wagner. The number of exuviae collected was reduced in the presence of intraguild predators. Yasuda \& Kimura (2001) also showed that the development of the young larvae of both $H$. axyridis and C. septempunctata was slowed in the presence of the crab spider Misumenops tricuspidatus (Fabricius), while older larvae of $H$. axyridis were not affected. Okuyama (2002), studying IGP among jumping spiders, demonstrated that IGP risk generated an indirect trait-mediated effect on the 
intraguild prey by decreasing its foraging activity. Such sublethal effects may alter coexistence of predators (survival, migration) in the system and aphid biological control.

In order to critically evaluate the impact of intraguild interaction, sublethal effects have to be addressed, which is rarely the case. Sublethal effect associated to IGP risk may change predator distribution, abundance, behaviour and consequently may favour or hamper biological control and/or coexistence of predatory species in the field.

\section{DEFENSIVE MECHANISMS AGAINST IGP}

The presence of IGP risk is associated with the presence of an array of defensive mechanisms, some of them being specific against intraguild predators, while others are directed toward both intra or extraguild threats. I modified the elegant functional classification of defensive mechanisms proposed by Endler $(1986,1991)$ to describe the successive lines of defense of intraguild prey.

\section{1st line, the encounter line}

The intraguild prey avoids encounter with the intraguild predator by selecting specific sites or periods. The selection of protected sites for the non-mobile (and highly vulnerable) stages is a common response to intraguild predation risk. Laboratory experiments tend to demonstrate that females of several aphidophagous species are able to identify fresh larval tracks (ODP, oviposition deterring pheromone, or ODK oviposition deterring kairomone) of potential intraguild predators for their eggs and avoid oviposition (Růžička, 1997; Doumbia et al., 1998; Růžička \& Havelka, 1998; Růžička \& Zemek, 2003). This remains to be tested in the field as it was done for intraspecific larval tracks (Fréchette et al., 2003). When comparing the strategies for moulting or pupating of the twelve-spotted lady beetle, Lucas et al. (2000) showed that the great majority of larval moults $(>60 \%)$ occurred on the potato plant in sites similar to those used by mobile larvae, while, in contrast, $90 \%$ of the larvae left the plant to pupate. The selection of a pupation site off the plant (far from aphid colony), compared to moulting sites, might be advantageous given a greater time of exposure to intraguild predation, reduced defensive ability compared to the 4th instar larvae, a reduced dependence on the food source (after pupation), and a greater capacity to disperse after pupation (as winged adult). Other aphidophagous predators may avoid encounter with intraguild predators during highly susceptible stages, such as the mirid eggs laid in plant stems (Kullenberg, 1944), or may protect themselves by co-occurring in the field with the intraguild predator only as older, less vulnerable stage (with smaller/younger intraguild predators) (Sato \& Dixon, 2004).

\section{2nd line, the detection line}

The intraguild prey reduces the probability of its detection and/or identification as a potential prey by the intraguild predator. As an example, the apod A. aphidimyza larva was not systematically detected or identified as a potential prey by lacewing larvae following a contact
(Lucas, unpubl.). Furthermore, midge protection may also rely on camouflage, since the midge's body is frequently covered by dead aphid corpses. Also, ovipositing females of the midge select preferentially pubescent sites on leaves close to an aphid colony, which enhances egg survival (Lucas \& Brodeur, 1999). Eggs of several species of lady beetles are protected by chemical compounds eliciting a repulsive response inhibiting predation by other lady beetle species (Hemptinne et al., 2000b).

\section{3rd line, the approach line}

Upon encounter, the intraguild prey avoids direct contact with the intraguild predator. Escape behaviour is one of the more common defensive mechanism recorded against intraguild predators (Lucas et al., 1997; Hindayana et al., 2001; Yasuda et al., 2001; Michaud \& Grant, 2003). It includes fleeing, dropping from the plant, displacing or retreating. This is especially the case with highly mobile predators like mirids. Also, most aerial adult stages may rely on escape behaviours to avoid being preyed by larval intraguild predators. This means that laboratory trials using small arenas may artificially enhance IGP levels.

\section{4th line, the subjugation line}

The intraguild prey avoids being subjugated by the intraguild predator. The sensory hairs of $H$. axyridis larvae may have protected them against the intraguild predator, the crab spider Misumenops tricuspidatus (Fabricius) (Yasuda \& Kimura, 2001). In C. septempunctata, the presence of dorsal spikes prevented successful attacks by E. balteatus larvae (Hindayana et al., 2001). Large larvae of $E$. balteatus used oral secretion (slime) to defend themselves against intraguild predators, and $C$. septempunctata released an orally secreted black defense fluid containing alkaloids which provokes predator retreat (Hindayana et al., 2001).

Adult Coleopteran species appeared to be very well protected against predation (but not invulnerable) and their defensive abilities seem to be associated mainly with their sclerified integument (Mallampalli et al., 2002; De Clercq et al., 2003) and possibly with their limuloid shape (such as in the case of lady beetles).

\section{5th line, the consumption line}

The intraguild prey avoids being consumed and digested by the intraguild predator. Eggs of several lady beetle species, for example Adalia bipunctata, are protected against intraguild predators by chemical compounds (Agarwala \& Dixon, 1992; Hemptinne et al., 2000a, b; Omkar et al., 2004). These compounds generated significant mortality in 4th instar larvae of C. septempunctata (see also Dixon, 2000). Phoofolo \& Obrycki (1998) showed that intraguild prey constituted a resource of varying value for the development of different intraguild predators: Chrysoperla carnea Stephens eggs were suitable prey for the development of $C$. maculata and $H$. axyridis but generated smaller adults, and did not allow the preimaginal development of C. septempunctata larva. C. carnea, when reared on C. maculata eggs, were also smaller, and they did not complete their development on 
H. axyridis eggs. However, these costs were related to a pure intraguild diet which is improbable in the field. Long spines of Curinus coeruleus Mulsant may have reduced their palatability as intraguild prey for other coccinellid species (Michaud \& Grant, 2003).

Finally, by exploiting gregarious extraguild prey, intraguild prey may avoid IGP by usurping aphid passive defences. These defences include (1) the encounter effect, since the individual's probability of being detected by an intraguild predator does not increase in direct proportion to group size (Inman \& Krebs, 1987), (2) the dilution effect, as the probability of being attacked after detection by an intraguild predator does not increase in direct proportion to group size (Edmunds 1974), and (3) the selfish herd effect, as the probability of being attacked for individuals in a central position in a group is lower than for individuals at the edges of the group (Hamilton, 1971). The midge $A$. aphidimyza by its furtive foraging behavior, benefits from a dilution effect generated by its prey which reduces the incidence of intraguild predation (Lucas \& Brodeur, 2001) and possibly from an encounter effect and from a selfish herd effect (Lucas et al., in prep.).

Of course, intraguild prey defensive systems usually include several successive defensive devices. As an example, the susceptibility of the ladybird C. maculata to predation by 3 rd instar $C$. rufilabris was age-specific and influenced by larval defensive strategies (Lucas et al., 1997). First and 2nd instars generally exhibit escape reactions (dropping, fleeing, retreating) but did not survive after being caught by lacewings, while 3rd and 4th instars, in addition to escape reactions (3rd line), defended themselves by wriggling or biting (4th line), even after being pierced by the lacewing. Eggs of the lady beetles Menochilus sexmaculatus (Fabricius) and of Coccinella transversalis (Fabricius) are protected against mutual IGP 1) by chemical defense and 2) by being laid in cluster (Agarwala \& Yasuda, 2001).

No defense has a total efficacy. In $6.9 \%$ of the cases, lacewing larvae circumvented the dropping behavior of the twelve spotted lady beetle either by falling with its prey without releasing it, or by holding the lady beetle in the air with its buccal hooks until the prey died (Lucas et al., 1997). In another example, lacewing eggs, despite the presence of the pedicel, were easily preyed upon by all stages of the twelve-spotted lady beetle (Lucas, 1998). Detailed observations showed that 1st instars grasped the stalk and climbed until they reached the base of the egg with their mandibles, 4th instars pushed the stalk over until they reached the egg, and adults stood on their hind legs and ate the egg directly off the stalk. Defenses therefore may or may not be efficient against intraguild predation, cannibalism, extraguild predation (by higher order predators), attacks by ants that attend at aphids, parasitism and/or pathogenous infection. However, most studies are designed to focus on the predator rather than the prey, and there is a need for assessing the adaptive value of the defensive mechanisms by testing them against an array of different threats. Finally, by activating the defensive mechanism of the intraguild prey, the intraguild predator may modify its susceptibility to another intraguild predator (or parasitoid, or cannibal, or higher order predator).

\section{HOW DO ANTS AFFECT IGP?}

Impact of ants on IGP may occur at two levels: first, ants may prey on aphids (and then belong to the guild), or second, ants may attend aphids and protect them against predators (Fig. 1). By exploiting aphid honeydew, ants may be considered in the aphidophagous guild; however, their status and ecological role is so specific that they should be considered separately. A little less than $75 \%$ of the aphid species are not tended by ants, and constitute potential prey for predatory ant species. IGP with aphidophagous predators is then probable but has not been documented. On the other hand, more than $25 \%$ of aphid species are tended by ants. Aphidophagous guilds are then regularly confronted with aphid-attending ants. Despite several papers on the impact of ants on aphidophagous species (Flanders, 1951; Banks, 1962; Buckley, 1987), few studies have described the possible impact of trophobiotic ants on interactions among aphidophagous predators. The impact of the ants on predators varies according to the ant species considered (Bristow, 1984). As an example, the red imported fire ant, Solenopsis invicta (Buren) tending Aphis gossypii Glover doubled aphid survival and reduced survival of lady beetle larvae by more than $90 \%$ and lacewing larvae by more than $80 \%$ (Kaplan $\&$ Eubanks, 2002). The abundance of fire ants was negatively correlated with the densities of 22 of 24 natural enemy taxa in cotton, and of 14 of 16 taxa in soybean (Eubanks, 2001; Eubanks et al., 2002). This suggests that managing to exploit aphids without suffering from ant attack would provide an enemy-free-space for the predator. Coccinella magnifica Redtenbacher is an aphidophagous species that lives close to Red Wood Ants' nests without being attacked, and is able to follow a recruitment trail laid by Formica polyctena Forester (Godeau et al., 2003). Kaneko (2002, 2003) showed that the parasitoid Lysiphlebus japonicus was encountered more often in aphid colonies tended by ants than in others. Ants, by attacking intraguild predators, conferred protection to parasitoids. The species of ant present also determined the occurrence of hyperparasitoids in an aphid colony. Recently, Brown (2004) demonstrated a positive association of several predators with aphid-attending ants. The relationship was the strongest with the midge $A$. aphidimyza. This may be related to the furtive behaviour of the predator (Lucas \& Brodeur, 1999). A. aphidimyza, which is very vulnerable to IGP (Lucas et al., 1998) takes benefit of aphid aggregation and may increase its benefit by preying on aphids attended by ants. Preliminary results by Guénard and colleagues (in prep.) showed that, in some instances, the predator was released from intraguild predation risk with specific ant species.

Despite some recent studies, the impact of ants on IGP, especially the indirect effect on interactions between aphidophagous predators, remains poorly understood. Considering the importance of ants in some natural sys- 
tems, it is very important to collect basic data on such topics as predator tolerance to ants according to ant species, density, ant/aphid ratio, ant colony size and distance.

\section{HOW DOES IGP AFFECT BIOLOGICAL CONTROL OF APHIDS?}

Since it is clear now that the previous one pest/one auxiliary program will not provide a solution to most phytosanitary problems, multi-specific releases of natural enemies should constitute a predominant tool against pest infestation. The impact of IGP on aphid biological control has generated much interest; however, no consensus has emerged from the different studies. The impact of the combined effect of several natural enemies (local and/or released) can generate three different outcomes: antagonistic (competition among natural enemies), additive (no competition, no facilitation) or synergistic (facilitation). In terms of IGP, two scenarios can be considered:

\section{The disruptive scenario}

IGP between the intraguild predator and the intraguild prey generates antagonistic effects on aphid control. In such a situation, the intraguild predator negatively affects the intraguild prey and indirectly releases aphid populations from their control. Models predict that IGP between predators should be disruptive for biological control (see Rosenheim et al., 1995). In alfalfa fields, the generalist carabid Pterostichus melanarius (Illiger) disrupted biological control of Acyrthosiphon pisum (Harris) by preying on mummies of the parasitoid Aphidius ervi (Haliday) (Snyder \& Ives, 2001). Ferguson \& Stiling (1996) demonstrated also that the effectiveness of parasitoids was reduced by interference between adult parasitoids and predators, and by IGP on parasitized aphids. In cotton, IGP of green lacewing eggs and larvae by Nabid, Lygaeid and Reduviid predators generated an increase in aphid populations (Rosenheim et al., 1993, 1999).

\section{The regulative scenario}

The simultaneous presence of intraguild predator and intraguild prey generates additive or synergistic effects leading to more effective control of the extraguild prey. Several hypotheses may explain such an effect. (1) The predatory species does not engage in IGP interactions; an example of such an effect was given by Losey \& Denno (1998), in a study on interactions between lady beetles and ground beetles both preying on pea aphids. Facilitation was observed because aphids, by dropping from the plant in response to an attack by the lady beetles, were more susceptible to predation by ground beetles. (2) The intraguild predator regulates the population of the intraguild prey and then indirectly regulates aphid populations. Snyder et al. (2004a) investigated the impact of simultaneous use of the predatory coccinellid $H$. axyridis and of the parasitoid Aphelinus asychis Walker on the control of the potato aphid, Macrosiphum euphorbiae Thomas, in greenhouses. Despite IGP by coccinellids on parasitoid mummies, the combination of natural enemies improved aphid control. The results could be explained by the fact that, in laboratory feeding trials, the lady beetle larvae preferred to feed on aphids rather than on mummies and adults had no preference, therefore increasing the ratio of mummies to aphids. In large cages, the ratio of aphids to mummies was not significantly altered by predator presence during 45 days. Another study by Snyder \& Ives (2003) in alfalfa, revealed that despite IGP of parasitoids by several predatory species, the percentage of aphids parasitized remained unchanged and the optimal control of aphids was achieved by combination of predators and parasitoids. Weisser (2003) demonstrated that, despite IGP by $C$. septempunctata larvae on $A$. ervi larvae within aphid hosts, the combined effect of predators and parasitoids was additive on the control of aphids, and that the greatest impact on aphid populations was obtained in the multispecific treatment. Another study (Colfer \& Rosenheim, 2001) in cotton fields demonstrated that, despite intense IGP by Hippodamia convergens Guerin-Meneville on parasitoid mummies, a density dependent response was observed leading to an increase in plant biomass. In this case, the effect resulted from a partial preference of the predator for unparasitized aphids over parasitized aphids, leading to an increase in the parasitized/unparasitized aphid ratio. Snyder \& Wise (2001) showed that the impact of a carabid-lycosid guild on striped cucumber beetle, Acalymma vittatum (Fabricius), early in the season increased cucumber yield. However, such an effect was not observed later in the season when the squash bug, Anasa nistis (DeGeer), became the main pest of the system, possibly due to IGP.

Globally, it remains difficult to assess the impact of IGP on aphid control. The positive or negative impact of IGP will depend on the guild structure and dynamics, which are influenced by intraguild factors (interactions among guild members), extraguild prey factors (aphid colony size, geometry, site, age, ...) host plant factors (height, phenology, defense, ...) natural enemy factors (higher-order predators), abiotic factors (perturbation, ...) and anthropic factors (economic threshold, type of biological control used). As stated by Ehler (1996), it is difficult to apply global theory to biological control situations, since the results will depend on specific problems related to the "plant-pest-guild-environment-program" selected. The occurrence of IGP may then have detrimental or beneficial impact depending on each local situation.

\section{CONCLUSION}

Intraguild predation is ubiquitous among aphidophagous predators and most predatory species are involved regularly in this type of interaction. The intensity of the interaction is highly variable depending on the different species implicated; however, it may constitute a predominant mortality factor in some species restricted or not to the role of intraguild prey.

Consequences of the interaction involve direct and indirect effect on each of the protagonists and possibly on other species. It appears especially important to study indirect effects on aphids and their control. Also, sublethal effects of IGP may have greater impact on the protagonists' ecology than lethal effects and should be taken 
into account in the studies. Intraguild predation research should include more open field studies with direct observations and experimental manipulations, and should link the results from the individual to the scale of the guild or the community. The link between IGP occurrence/intensity and the final outcome (coexistence, aphid control) observed in the fields remains difficult to establish. The long-term consequences of IGP are also poorly understood, and it is important to conduct long term studies notably on the structure and dynamic of the guild. Intraguild predation studies should also consider the interguild consequences, since several polyphagous predators belong also to acarophagous, aleurophagous or other guilds. This is especially important in a classical, inoculative or conservative biological control perspective.

Several other important questions related to IGP were not treated here and have to be considered, such as the coexistence of intraguild prey and predators (see Holt \& Polis, 1997; Obrycki et al., 1998a, b; Schellhorn \& Andow, 1999a; Heithaus, 2001; Mylius et al., 2001) or the impact of invasive species on local guilds (Obrycki et al., 1998b; Kajita et al., 2000; Lucas et al., 2002; Evans, 2004 and references therein). The exact contribution of IGP in these processes remains to be clarified. Beyond the interaction, it is the structure (at different spatial scales) and the dynamic (at different time scales) of the aphidophagous guild which have to be studied. Finally, IGP among aphidophagous predators involves at least three trophic levels and four protagonists (intraguild predator, intraguild prey, extraguild prey and plant; and possibly ant). Studying such a complex interaction involves logistic and conceptual challenges not easy to resolve, but the emergence of new tools, in observation (Meyhöfer, 2001), modeling (Křivan, 2000; Heithaus, 2001; Okuyama \& Ruyle, 2003), and statistics (Sih et al., 1998) may help to understand the ecology of IGP and other intraguild interactions.

ACKNOWLEDGEMENTS. This research was supported by grants from NSERC (Canada) and FQRNT (Quebec) to É. Lucas. I am grateful to E.W. Evans, A.O. Soares, B. Fréchette, and to G. Labrie for their helpful comments on preliminary versions of the manuscript.

\section{REFERENCES}

Agarwala B.K. \& Dixon A.F.G. 1992: Laboratory study of cannibalism and interspecific predation in ladybirds. Ecol. Entomol. 17: 303-309.

Agarwala B.K. \& Yasuda H. 2001: Overlaping oviposition and chemical defense of eggs in two co-occurring species of ladybird predators of aphids. J. Ethol. 19: 47-53.

Agoiz-Bustamante J.L. 2001: Un agresivo comportamiento alimentario de Aphodius (Ammoecius) lusitanicus Erichson, 1848 y nuevos datos sobre su corologia y tropismo (Coleoptera, Scarabaeoidea, Aphodiidae). Bol. Soc. Entomol. Aragon. 29: 79-80.

Babendreier D., Rostas M., Höfte M.C.J., Kuske S. \& Bigler F. 2003: Effects of mass releases of Trichogramma brassicae on predatory insects in maize. Entomol. Exp. Appl. 108: 115-124.
BANKs C.J. 1962: Effects of the ant Lasius niger on insects preying on small populations of Aphis fabae on bean plants. Ann. Appl. Biol. 50: 669-679.

Blackith R. \& BLACKith R. 1984: Larval aggression in Irish flesh-flies (Diptera: Sarcophagidae). Irish Nat. J. 21: 255-257.

BROWN M.W. 2004: Role of aphid predator guild in controlling spirea aphid populations on apple in West Virginia, USA. Biol. Control 29: 189-198.

BRISTOw C.M. 1984: Differential benefits from ant attendance to two species of homoptera on New York ironweed. J. Anim. Ecol. 53: 715-726.

Brodeur J. \& Boivin G. 2004: Functional ecology of immature parasitoids. Annu. Rev. Entomol. 49: 27-49.

BRODEUR J. \& RoSENHEIM J.A. 2000: Intraguild predation in aphid parasitoids. Entomol. Exp. Appl. 97: 93-108.

BUCKLEY R.C. 1987: Interactions involving plants, Homoptera, and ants. Annu. Rev. Ecol. Syst. 8: 111-135.

Burgio G., Santi F. \& Maini S. 2002: On intra-guild predation and cannibalism in Harmonia axyridis (Pallas) and Adalia bipunctata L. (Coleoptera: Coccinellidae). Biol. Control 24: $110-116$.

ChANG G.C. 1996: Comparison of single versus multiple species of generalist predators for biological control. Environ. Entomol. 25: 207-622

Clancy K.M. \& Price P.W. 1987: Rapid herbivore growth enhances enemy attack: sublethal plant defenses remain a paradox. Ecology 68: 736-738.

Cloutier C. \& Johnson S.G. 1993: Predation by Orius tristicolor (Hemiptera: Anthocoridae) on Phytoseiulus persimilis (Acarina: Phytoseiidae): Testing for compatibility between biocontrol agents. Environ. Entomol. 22: 477-482.

Colfer R.G. \& Rosenheim J.A. 2001: Predation on immature parasitoids and its influence of aphid population suppression. Oecologia 126: 292-304.

Corbet P.S. \& GRIFFiths A. 1963: Observations on the aquatic stages of two species of Toxorhynchites (Diptera: Culicidae) in Uganda. Proc. R. Entomol. Soc. Lond. (A) 38: 125-135.

Cottrell T.E. \& Yeargan K.V. 1998: Intraguild predation between an introduced lady beetle Harmonia axyridis (Coleoptera: Coccinellidae), and a native lady beetle, Coleomegilla maculata (Coleoptera: Coccinellidae). J. Kans. Entomol. Soc. 71: $159-163$.

De Clerce P., Peters I., Vergauwe G. \& Thas O. 2003: Interaction between Podisus maculiventris and Harmonia axyridis, two predators used in augmentative biological control in greenhouse crops. BioControl 48: 39-55.

Dixon A.F.G. 1985: Aphid Ecology. Blackie, Chapman and Hall, New York, USA, 157 pp.

Dixon A.F.G. 1987: Parthenogenetic reproduction and the rate of increase in aphids. In Minks A.K. \& Harrewijn P. (eds): World Crop Pests; Aphids, their Biology, Natural Enemies and Control. Vol. A. Elsevier, Amsterdam, The Netherlands, pp. 269-287.

Dixon A.F.G. 2000: Insect Predator-Prey Dynamic; Ladybird Beetles and Biological Control. Cambridge University Press, Cambridge, UK, $257 \mathrm{pp}$.

Doumbia M., Hemptinne J.-L. \& Dixon A.F.G. 1998: Assessment of patch quality by ladybirds: role of larval tracks. Oecologia 113: 197-202.

Edmunds M. 1974: Defence in Animals. Longman, New York, USA, $357 \mathrm{pp}$

EHLER L.E. 1996: Structure and impact of natural enemy guilds in biological control of insect pests. In Polis G.A. \& Winemiller K.O. (eds): Food Webs; Integration of Patterns and Dynamics. Chapman \& Hall, Toronto, Canada, pp. 337-342. 
EndLer J.A. 1986: Defense against predators. In Feder M.E. \& Lauder G.V. (eds): Predator-Prey Relationships: Perspectives and Approaches from the Study of Lower Vertebrates. University of Chicago Press, Chicago, USA, pp. 109-134.

ENDLER J.A. 1991: Interactions between predators and prey. In Krebs J.R. \& Davies N.B. (eds): Behavioural Ecology; An Evolutionary Approach. Blackwell Scientific Publications, Oxford, UK, pp. 169-202.

ENGLUND G. 1997: Importance of spatial scale and prey movements in predator caging experiments. Ecology $\mathbf{7 8}$ $2316-2325$.

EuBANKS M.D. 2001: Estimates of the direct and indirect effects of red imported fire ants on biological control in field crops. Biol. Control 21: 35-43.

Eubanks M.D., Blackwell S.A., Parrish C.J., Delamar Z.D. \& Hull-SANDERS H. 2002: Intraguild predation of beneficial arthropods by red imported fire ants in cotton. Environ. Entomol. 31: 1168-1174.

Evans E.W. 2004: Habitat displacement of North American ladybirds by an introduced species. Ecology 85: 637-665.

FÉlIX S. \& SoAres A.O. 2004: Intraguild predation between the aphidophagous ladybird beetles Harmonia axyridis and Coccinella undecimpunctata (Coleoptera: Coccinellidae): the role of bodyweight. Eur. J. Entomol. 101: 237-242.

Ferguson K.I. \& Stiling P. 1996: Non-additive effects of multiple natural enemies on aphid populations. Oecologia 108: 375-379.

FLANDERS S.E. 1951: The role of the ant in the biological control of Homopterous insects. Can. Entomol. 83: 93-98.

Fréchette B., Alauzet C. \& Hemptinne J.-L. 2003: Oviposition behaviour of the two-spot ladybird beetle Adalia bipunctata (L.) (Coleoptera: Coccinellidae) on plants with conspecific larval tracks. Arquipelago, Life Mar. Sci. (Suppl.) 5: 73-77.

Godeau J.-F., Hemptinne J.-L. \& Verhaeghe J.C. 2003: Ant trail: a highway for Coccinella magnifica Redtenbacher (Coleoptera: Coccinellidae). Arquipelago, Life Mar. Sci. (Suppl.) 5: 79-83.

HAMILTON W.D. 1971: Geometry for the selfish herd. J. Theor. Biol. 31: 295-311.

HANSKI I. 1987: Nutritional ecology of dung- and carrionfeeding insects. In Slansky F. Jr. \& J.G. Rodriguez (eds): Nutritional Ecology of Insects, Mites, Spiders, and Related Invertebrates. Wiley, New York, USA, pp. 837-884.

Heithaus M.R. 2001: Habitat selection by predators and prey in communities with asymmetrical intraguild predation. Oikos 92: $542-554$.

Hemptinne J.-L., Dixon A.F.G. \& Gauthier C. 2000a: Nutritive cost of intraguild predation on eggs of Coccinella septempunctata and Adalia bipunctata (Coleoptera: Coccinellidae). Eur. J. Entomol. 97: 559-562.

Hemptinne J.-L., Lognay G., Gauthier C. \& Dixon A.F.G. 2000b: Role of surface chemical signals in egg cannibalism and intraguild predation in ladybirds (Coleoptera: Coccinellidae). Chemoecology 10: 123-128.

Hindayana D., Meyhöfer R., Scholz D. \& Poehling H.-M. 2001: Intraguild predation among the hoverfly Episyrphus balteatus de Geer (Diptera: Syrphidae) and other aphidophagous predators. Biol. Control 20: 236-246.

Hironori Y. \& Katsuhiro S. 1997: Cannibalism and interspecific predation in two predatory ladybirds in relation to prey abundance in the field. Entomophaga 42: 153-163.

Hodek I. 1996: Food relationships. In Hodek I. \& Honěk A. (eds): Ecology of Coccinellidae. Kluwer Academic Publishers, Boston, USA, pp. 143-238.
Hodge M.A. 1999: The implications of intraguild predation for the role of spiders in biological control. J. Arachnol. 27: 351-362.

Holt R.D. \& Polis G.A. 1997: A theoretical framework for intraguild predation. Am. Nat. 149: 745-764.

InMAN A.J. \& KREBS J. 1987: Predation and group living. Trends Ecol. Evol. 2: 31-32.

JoHANSSON F. 1993: Intraguild predation and cannibalism in odonate larvae: effects of foraging behaviour and zooplankton availability. Oikos 66: 80-87.

Kajtta Y., Takano F., Yasuda H. \& Agarwala B.K. 2000: Effects of indigenous ladybird species (Coleoptera: Coccinellidae) on the survival of an exotic species in relation to prey abundance. Appl. Entomol. Zool. 35: 473-479.

KANEKO S. 2002: Aphid-attending ants increase the number of emerging adults of the aphid's primary parasitoids and hyperparasitoids by repelling intraguild predators. Entomol. Sci. 5: 131-146.

KaneKo S. 2003: Different impacts of two species of aphid attending ants with different aggressiveness on the number of emerging adults of the aphid's primary parasitoid and hyperparasitoids. Ecol. Res. 18: 199-713.

Kaplan I. \& EubanKs M.D. 2002: Disruption of cotton aphid (Homoptera: Aphididae) - natural enemy dynamics by red imported fire ants (Hymenoptera: Formicidae). Environ. Entomol. 31: 1175-1183.

Ǩ̈IVAN V. 2000: Optimal intraguild foraging and population stability. Theor. Popul. Biol. 58: 79-94.

Kullenberg B. 1944: Studien über die Biologie der Capsiden. Zool. Bidrag Från Uppsala (Suppl.) 23: 1-522.

LANG A. 2003: Intraguild interference and biocontrol effects of generalist predators in a winter wheat field. Oecologia 134: 144-153.

LAURENSEN M.K. 1994: High juvenile mortality in cheetahs (Acinonyx jubatus) and its consequences for mutual care. $J$. Zool. 234: 387-398.

Lima S.L. 1998: Nonlethal effects in the ecology of predatorprey interactions: What are the ecological effects of antipredator decision making? Bioscience 48: 25-34.

Lima S.L. \& Dill L.M. 1990: Behavioural decisions made under the risk of predation: a review and prospectus. Can. J. Zool. 68: $610-640$.

Losey J.E. \& DenNo R.F. 1998: Positive predator-predator interactions: enhanced predation rates and synergistic suppression of aphid populations. Ecology 79: 2143-2152.

LUCAS É. 1998: How do ladybirds (Coleomegilla maculata lengi, Coleoptera: Coccinellidae) feed on green lacewing eggs (Chrysoperla rufilabris, Neuroptera: Chrysopidae). Can. Entomol. 130: 547-548.

Lucas É. \& Alomar O. 2000: Susceptibilité de Macrolophus caliginosus (Heteroptera: Miridae) à la prédation intraguilde. IOBC/WPRS Bull. 23: 225-229.

LuCAS É. \& Alomar O. 2001: Macrolophus caliginosus (Wagner) as an intraguild prey for the zoophytophagous Dicyphus tamaninii Wagner (Heteroptera: Miridae). Biol. Control. 20: 147-152.

LuCAS É. \& Alomar O. 2002a: Impact of Macrolophus caliginosus presence on damage production by Dicyphus tamaninii (Heteroptera: Miridae) on tomato fruits. J. Econ. Entomol. 95: 1123-1126.

Lucas É. \& Alomar O. 2002b: Impact of the presence of Dicyphus tamaninii Wagner (Heteroptera: Miridae) on whitefly (Homoptera: Aleyrodidae) predation by Macrolophus caliginosus (Wagner) (Heteroptera: Miridae). Biol. Control. 25: 123-128. 
Lucas É. \& Brodeur J. 1999: Oviposition site selection by Aphidoletes aphidimyza Rondani (Diptera: Cecidomyiidae). Environ. Entomol. 28: 622-627.

Lucas É. \& Brodeur J. 2001: A fox in a sheep-clothing: dilution effect for a furtive predator living inside prey aggregation. Ecology 82: 3246-3250.

Lucas Ė., Coderre D. \& Brodeur J. 1997: Instar-specific defense of Coleomegilla maculata lengi (Coccinellidae): influence on attack success of the intraguild predator Chrysoperla rufilabris (Chrysopidae). Entomophaga 42: 3-12.

Lucas É., Coderre D. \& Brodeur J. 1998: Intraguild predation among aphid predators: characterization and influence of extraguild prey density. Ecology 79: 1084-1092.

Lucas É., Coderre D. \& Brodeur J. 2000: Selection of molting and pupating site by Coleomegilla maculata lengi Timberlake (Coleoptera: Coccinellidae): Avoidance of intraguild predation? Environ. Entomol. 29: 454-459.

Lucas É., Gagné I. \& Coderre D. 2002: Impact of the arrival of Harmonia axyridis on adults Coccinella septempunctata and Coleomegilla maculata (Coleoptera: Coccinellidae). Eur. J. Entomol. 99: 457-463.

Mallampalli N., Castellanos I. \& Barbosa P. 2002: Evidence for intraguild predation by Podisus maculiventris on a ladybeetle, Coleomegilla maculata: Implications for biological control of Colorado potato beetle, Leptinotarsa decemlineata. BioControl 47: 387-398.

MEYHÖFER R. 2001: Intraguild predation by aphidophagous predators on parasitized aphids: the use of multiple video cameras. Entomol. Exp. Appl. 100: 77-87.

Michaud J.P. 2002: Invasion of the Florida citrus ecosystem by Harmonia axyridis (Coleoptera: Coccinellidae) and asymmetric competition with a native species, Cycloneda sanguinea. Environ. Entomol. 31: 827-835.

Michaud J.P. 2004: Natural mortality of Asian psyllid (Homoptera: Psyllidae) in central Florida. Biol. Control 29: 260-269.

Michaud J.P. \& Grant A.K. 2003: Intraguild predation among ladybeetles and a green lacewing: do the larval spines of Curinus coeruleus (Coleoptera: Coccinellidae) serve as a defensive function? Bull. Entomol. Res. 93: 499-505.

Minks A.K. \& Harrewisn P. (eds) 1988: World Crop Pests; Aphids, their Biology, Natural Enemies and Control. Vol. B. Elsevier, Amsterdam, The Netherlands, $384 \mathrm{pp}$.

Müller C.B. \& Brodeur J. 2002: Intraguild predation in biological control and conservation biology. Biol. Control 25: 216-223.

Mylius S.D., Klumpers K., de Roos A.M. \& Persson L. 2001: Impact of intraguild predation and stage structure on simple communities along a productivity gradient. Am. Nat. 158: 259-276.

Nijveldt W. 1988: Cecidomyiidae. In Minks A.K. \& Harrewijn P. (eds): World Crop Pests; Aphids, their Biology, Natural Enemies and Control. Vol. A. Elsevier, Amsterdam, The Netherlands, pp. 271-277.

ObrycKi J.J., Giles K.L. \& Ormord A.M. 1998a: Experimental assessment of interactions between larval Coleomegilla maculata and Coccinella septempunctata (Coleoptera: Coccinellidae) in field cages. Environ. Entomol. 27: 1280-1288.

OBRYCKi J.J., Giles K.L. \& ORMORd A.M. 1998b: Interactions between an introduced and indigenous coccinellid species at different prey densities. Oecologia 117: 279-285.

OKuYAMA T. 2002: The role of antipredator behavior in an experimental community of jumping spiders with intraguild predation. Popul. Ecol. 44: 121-125.

OKuYama T. \& RuYLE R.L. 2003: Analysis of adaptive foraging in an intraguild predation system. Web Ecol. 4: 1-6.
Omkar G.M. \& Pervez A. 2002: Intraguild predation by ladybeetles: An ultimate survival strategy or an aid for advanced aphid biocontrol? In Prof. S.B. Singh Comm. Vol. Zool. Soc. India, pp. 77-90.

Omkar G.M., Pervez A. \& Gupta A.K. 2004: Role of surface chemicals in egg cannibalism and intraguild predation by neonates of two aphidophagous ladybirds, Propylea dissecta and Coccinella transversalis. J. Appl. Entomol. 128: 691-695.

Рноofolo M.W. \& OвRYскі J.J. 1998: Potential for intraguild predation and competition among predatory Coccinellidae and Chrysopidae. Entomol. Exp. Appl. 89: 47-55.

Polis G.A. \& Holt R.D. 1992: Intraguild predation: The dynamics of complex trophic interactions. Trends Ecol. Evol. 7: $151-154$

Polis G.A., Myers C.A. \& Holt R.D. 1989: The ecology and evolution of intraguild predation: Potential competitors that eat each other. Annu. Rev. Ecol. Syst. 20: 297-330.

PrinciPI M.M. \& CANARD M. 1984: Feeding habits. In Canard M., Semeria Y. \& New T.R. (eds): Biology of Chrysopidae. Dr. Junk, The Hague, The Netherlands, pp. 76-92.

Provost C., Coderre D., Lucas É. \& Bostanian N.J. 2003a: Impacts of Lambda-cyhalothrin on intraguild predation among three mite predators. Environ. Entomol. 32: 256-263.

Provost C., Coderre D., Lucas É. \& Bostanian N.J. 2003b: Impact d'une dose sublétale de lambda-cyhalothrine sur les prédateurs intraguildes d'acariens phytophages en verger de pommiers. Phytoprotection 84: 105-113.

Rоoт R. 1967: The niche exploitation pattern of the blue-grey gnat catcher. Ecol. Monogr. 37: 317-350.

ROSENHEIM J.A. 1998: Higher-order predators and the regulation of insect herbivore populations. Annu. Rev. Entomol. 43: 421-447.

Rosenheim J.A., Wilhoit R. \& Armer C.A. 1993: Influence of intraguild predation among generalist insect predators on the suppression of an herbivore population. Oecologia 96: 439-449.

Rosenheim J.A., Kaya H.K., Ehler L.E., Marois J.J. \& Jaffee B.A. 1995: Intraguild predation among biological control agents: Theory and evidence. Biol. Control 5: 303-335.

Rosenheim J.A., Limburg D.D. \& Colfer R.G. 1999: Impact of generalist predators on a biological control agent, Chrysoperla carnea: Direct observations. Ecol. Appl. 9: 409-417.

Roy H.E., Alderson P.G. \& Pell J.K. 2003: Effect of spatial heterogeneity on the role of Coccinella septempunctata as an intra-guild predator of the aphid pathogen Pandora neoaphidis. J. Invertebr. Pathol. 82: 85-95.

Rozas L., Avila J.M. \& Sanchez-Pinero F. 1991: Observación de hábitos depredadores en Hybosorus illgeri Reiche, 1853 (Coleoptera, Scarabaeoidea, Hybosoridae). Bol. Assoc. Esp. Entomol. 15: 111-115.

RŮŽIČKA Z. 1997: Recognition of oviposition-deterring allomones by aphidophagous predators (Neuroptera: Chrysopidae, Coleoptera: Coccinellidae). Eur. J. Entomol. 94: 431-434.

RŮŽIČKA Z. \& HAVELKA J. 1998: Effects of oviposition-deterring pheromone and allomones on Aphidoletes aphidimyza (Diptera: Cecidomyiidae). Eur. J. Entomol. 95: 211-216.

RŮŽIČKA Z. \& ZEMEK R. 2003: Effects of conspecific and heterospecific larval tracks on mobility and searching patterns of Cycloneda limbifer Say (Coleoptera: Coccinellidae) females. Arquipelago, Life Mar. Sci. (Suppl.) 5: 85-93.

Sato S. \& Dixon A.F.G. 2004: Effect of intraguild predation on the survival and development of three species of aphidophagous ladybirds: consequences for invasive species. Agric. For. Entomol. 6: 21-24. 
Sato S., Dixon A.F.G. \& Yasuda H. 2003: Effect of emigration on cannibalism and intraguild predation in aphidophagous ladybirds. Ecol. Entomol. 28: 628-633.

SCHELlHorn N.A. \& ANDOw D.A. 1999a: Cannibalism and interspecific predation: role of oviposition behavior. Ecol. Appl. 9: 418-428.

SCHELLHORN N.A. \& ANDOw D.A. 1999b: Mortality of coccinellid (Coleoptera: Coccinellidae) larvae and pupae when prey become scarce. Environ. Entomol. 28: 1092-1100.

Sengonca C. \& Frings B. 1985: Interference and competitive behaviour of the aphid predators, Chrysoperla carnea and Coccinella septempunctata in the laboratory. Entomophaga 30: $245-251$.

SHAPOSHNIKov G.C. 1988: Organization (structure) of population and species, and speciation. In Minks A.K. \& Harrewijn P. (eds): World Crop Pests; Aphids, their Biology, Natural Enemies and Control. Vol. A. Elsevier, Amsterdam, The Netherlands, pp. 415-430.

Sin A., Englund G. \& Wooster D. 1998: Emergent impacts of multiple predators on prey. Trends Ecol. Evol. 13: 350-355.

SNYDER W.E. \& Ives A.R. 2001: Generalist predators disrupt biological control by a specialist parasitoid. Ecology 82: 705-716.

SNYDER W.E. \& Ives A.R. 2003: Interactions between specialist and generalist natural enemies: parasitoids, predators, and pea aphid biocontrol. Ecology 84: 91-107.

SNyder W.E. \& Wise D.H. 2001: Contrasting trophic cascades generated by a community of generalist predators. Ecology 82: $1571-1583$.

Snyder W.E., Ballard S.N., Yang S., Clevenger G.M., Miller T.D., Ahn J.J., Hatten T.D. \& Berryman A.A. 2004a: Complementary biocontrol of aphids by the ladybird beetle Har- monia axyridis and the parasitoids Aphelinus asychis on greenhouse roses. Biol. Control. 30: 229-235.

Snyder W.E., Clevenger G.M. \& Eigenbrode S.D. 2004b: Intraguild predation and successful invasion by introduced ladybird species. Oecologia 140: 559-565.

Szeinfeld E.V. 1991: Cannibalism and intraguild predation in clupeoids. Mar. Ecol. Prog. Ser. 79: 17-26.

WEISSER W.W. 2003: Additive effects of pea aphid natural enemies despite intraguild predation. Arquipelago, Life Mar. Sci. (Suppl.) 5: 11-15.

White C. \& Eigenbrode S.D. 2000: Leaf surface waxbloom in Pisum sativum influences predation and intra-guild interactions between two predator species. Oecologia 124: 252-259.

Wise D.H. 1993: Spiders in Ecological Webs. Cambridge University Press, Cambridge, UK, 328 pp.

YASUDA H. \& KimURA T. 2001: Interspecific interactions in a tritrophic arthropod system: effects of a spider on the survival of larvae of three predatory ladybirds in relation to aphids. Entomol. Exp. Appl. 98: 17-25.

Yasuda H. \& OHNuma N. 1999: Effect of cannibalism and predation on the larval performance of two ladybird beetles. Entomol. Exp. Appl. 93: 63-67.

Yasuda H., KikUChI T., Kindlmann P. \& Sato S. 2001: Relationships between attack and escape rates, cannibalism, and predation in larvae of two predatory ladybirds. J. Insect Behav. 14: 373-384.

Yasuda H., Evans E.W., KajtTa Y., Urakawa K. \& Takizawa T. 2004: Asymmetric larval interactions between introduced and indigenous ladybirds in North America. Oecologia 141: 722-731.

Received January 6, 2005; revised February 28, 2005; accepted March 7, 2005 
